\title{
The Mode of Action of Maleic Hydrazide: Inhibition of Growth
}

\author{
By \\ LARRY D. NOODÉN \\ Department of Botany, University of Michigan \\ Ann Arbor, Michigan 48104
}

(Received May 21, 1968)

\begin{abstract}
Maleic hydrazide (MH) inhibits corn root elongation through an effect on cell division apparently without inhibiting cell enlargement. The decrease in the rate of elongation was apparent only after a considerable lag, over 14 hours, even with a concentration as high as $5 \mathrm{~m} M$. MH $(1 \mathrm{mM})$ did not inhibit the growth of roots from corn seeds given very large doses of $\gamma$-irradiation or excised corn root segments including the elongation zone or the cell enlargement induced by IAA in corn coleoptile sections. Many compounds including purines, pyrimidines, nucleosides, cysteine, pyridoxal, pyruvate, kinetin and $\mathrm{CoCl}_{2}$, many of which had previously been reported to alleviate $\mathrm{MH}$ inhibition in other tissues, were tested for their ability to prevent the inhibition of corn root elongation by $\mathrm{MH}$, but none were effective. These data do not support the theory that $\mathrm{MH}$ acts by inhibiting the synthesis of or competing with some simple metabolite or hormone. Whatever its mechanism of action the failure of $\mathrm{MH}$ to inhibit cell enlargement in most systems indicates that it is fairly selective.
\end{abstract}

\section{Introduction}

For about 20 years maleic hydrazide has been studied extensively as an inhibitor of plant development and as an antimitotic agent $(3,11,13,31)$. Of special interest are the developmental aberrations $(29,30)$ and chromosome breakage $(13,16,18)$ resulting from MH treatment. The structural requirements for its activity are known to include the heterocyclic ring and an $\mathrm{OH}$ (maleic hydrazide ordinarily exists as the enol in solution, see 11, 12, 16). The biochemical mechanism(s) by which MH affects plant development or causes chromosome breakage are still unknown $(3,11,13,31)$. 
Knowledge of the biochemical effects of $\mathrm{MH}$ or the mechanism(s) of action of maleic hydrazide would be very useful in tying together many developmental and cytogenetic studies with some specific metabolic processes. In this paper the effects of $\mathrm{MH}$ on cell enlargement and division are reported along with attempts to prevent inhibition of cell division by $\mathrm{MH}$ with several metabolites.

Abbreviations: FU: fluorouracil; FUdR: fluorodeoxyuridine; MH: maleic hydrazide.

\section{Materials and Methods}

The corn seeds (Zea mays L.) used in these experiments were Michigan $250 \mathrm{RF}$ Hybrid seed corn (yellow field corn) and Burpee's Barbecue Hybrid (yellow sweet corn). These seeds were soaked in $0.25 \%$ (w/v) NaClO for 15 minutes and then placed in running tap water (about $30^{\circ} \mathrm{C}$ ) for $8-10$ hours. The seeds were then grown in moistened vermiculite at $25^{\circ} \mathrm{C}$ for about 48 hours from the start of the soak to obtain roots and about 4 days for coleoptiles. Subapical sections $2 \mathrm{~cm}$ long were taken from the coleoptiles as described before (22). The coleoptile sections were floated on water with or without IAA or MH and subjected to rotary shaking. Sections of the corn seedling roots with or without the tips were shaken in the

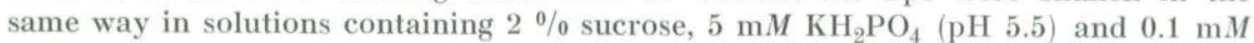
pyridoxal.

For some experiments dry Michigan Hybrid corn seed was irradiated with $\gamma$-rays from ${ }^{60} \mathrm{Co}$ by the University of Michigan Radiation Control Service. After at least a couple of days of dry, cold storage, these seeds were germinated and grown as before except that sterilizing the vermiculite by autoclaving was necessary to prevent the growth of fungi around the seeds. Since the roots of the irradiated seeds grow less rapidly than those from unirradiated seeds, they needed a little more time to reach the required length.

The Alaska peas (Pisum sativum L.) were soaked in tap water for 4-5 hours and then germinated on trays between moist paper towels at $25^{\circ} \mathrm{C}$. The temperature of the water used to soak the peas was $25-30^{\circ} \mathrm{C}$; cold water resulted in very poor roots.

To study root elongation, seedlings with rapidly growing roots were selected, washed with distilled water and placed on racks with the roots sticking down into the treatment solutions, which were aerated by bubbling air through the treatment solutions. The root sections were incubated in flasks with rotary shaking.

All experiments were done at $25^{\circ} \mathrm{C}$ in dim red light.

Stock solutions of $10 \mathrm{mM} \mathrm{MH}$ and $100 \mathrm{mg} / \mathrm{l}$ IAA, both acidic, were adjusted to $\mathrm{pH} 5.50$ with $\mathrm{NaOH}$. Likewise the $\mathrm{pH}$ of other solutions was adjusted to 5.50 where necessary. The MH was obtained from Sigma Chemical Co. and for most experiments it was recrystallized from distilled water at least 5 times.

The artichoke tuber disks were prepared and treated as described earlier (22). Tobacco pith explants were cultured on agar with $2 \mathrm{mg} / 1$ IAA and other additives according to Murashige and Skoog (21) excepting kinetin.

\section{Results and Discussion}

Without a doubt, MH at the appropriate concentration inhibits cell division in plants $(3,11,13,16,18,30,31)$; however, there is still some uncer- 


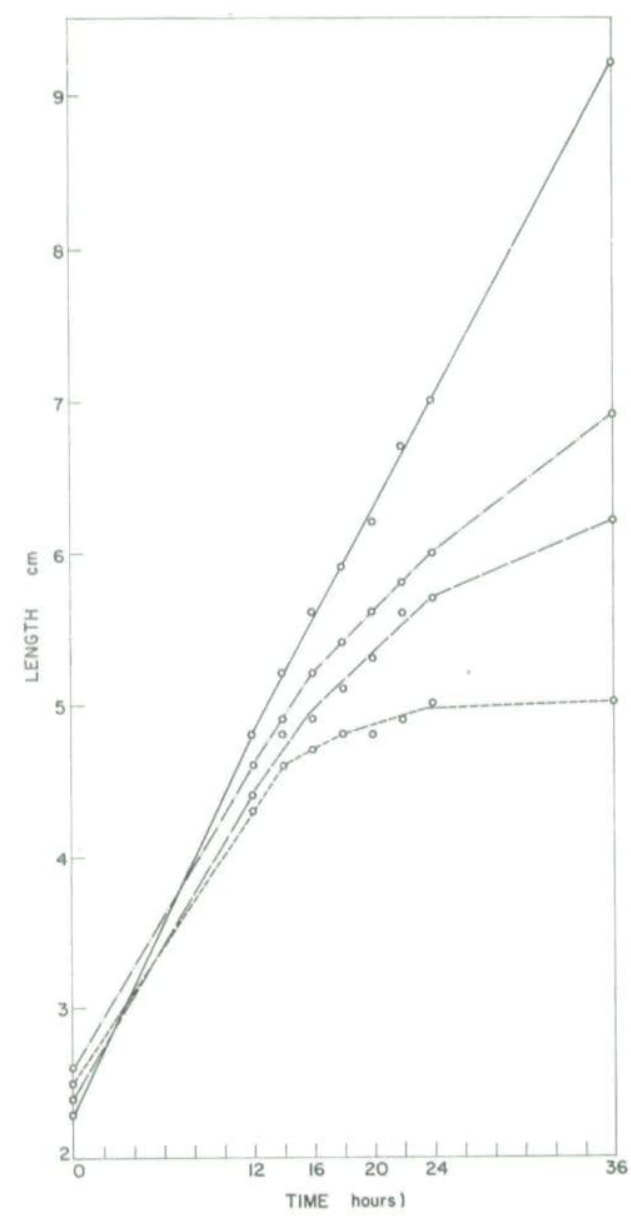

Figure 1. Kinetics of inhibition of corn root elongation by maleic hydrazide, effects of varying concentrations. (-) control, no maleic hydrazide; (-..--) $0.5 \mathrm{mM}$; $(--) 1 \mathrm{~m} M$; (-.) $5 \mathrm{~m} M$ maleic hydrazide.

tainty about its effects on cell enlargement especially that induced by auxin $(1,6,7,8,9,10,11,15,26,28,30,31)$. Although $\mathrm{MH}$ does not seem to inhibit cell enlargement in most cases, it was considered necessary to re-examine this problem in connection with experiments on its mode of action. Corn seedlings, the roots in particular, were chosen as the principal material for study.

First, it was determined what concentrations of $\mathrm{MH}$ were required to inhibit elongation. As with the growth of flax roots (1), concentrations of $0.1 \mathrm{~m} M$ or above show a distinct inhibition of the elongation of corn roots submerged in aerated solutions (Figure 1). Because the purity of reagent MH has been questioned recently (17), the MH was recrystallized from water 5 times or more, but recrystallization did not produce any change in the ability of various concentrations of $\mathrm{MH}$ to inhibit root elongation.

Figure 1 shows that the time required for inhibition of root elongation is rather long, more than 12 hours, but it is influenced by the concentration of 
$\mathrm{MH}$ indicating that the rate of uptake of $\mathrm{MH}$ may be important in determining the kinetics of inhibition. At all concentrations tested there is a considerable time lag before inhibition of growth starts. With $1 \mathrm{mM} \mathrm{MH}$, the concentration chosen for physiological studies, the inhibition of root elongation begins after about 16 hours. In similar experiments with pea roots, $1 \mathrm{mM}$ MH inhibited elongation from about 24 hours onward.

The next question which arises is: does $\mathrm{MH}$ affect root elongation through inhibition of cell division and/or enlargement? This problem was approached experimentally in three ways: (a) by testing the effect of $\mathrm{MH}$ on roots growing without cell division from $\gamma$-irradiated corn seeds, (b) by comparing MH with another inhibitor, fluorouracil, which also appears to inhibit cell division without affecting cell enlargement, and (c) by examining the effect of $\mathrm{MH}$ on root segments which include the elongation zone.

Since corn seeds which have been given massive doses of $\gamma$-irradiation produce roots which grow by cell enlargement only (24), it is possible to see if maleic hydrazide can inhibit growth independent of its effect on cell division. The elongation of roots produced by the irradiated seeds is not inhibited by $1 \mathrm{~m} M \mathrm{MH}$ (Figure 2) as would be expected if $\mathrm{MH}$ inhibited growth through inhibition of cell division alone. Haber and White (10) have also reported tests on the effect of $\mathrm{MH}$ (supplied via the roots) on the growth of seedlings from $\gamma$-irradiated wheat. MH reduced the growth of the leaves from unirradiated seeds but not those from irradiated seeds. Since there is some uncertainty as to whether enough $\mathrm{MH}$ to inhibit cell expansion can get up into the leaves in the $\gamma$-plantlets and the organs studied here were roots not leaves, these experiments were done with corn roots to confirm and extend the earlier studies by Haber and White.

Fluorouracil, also an inhibitor of cell division in roots (4), likewise does not affect the elongation of roots from irradiated seeds, although it does inhibit the growth of roots from unirradiated seeds after a time lag similar to that with MH. A related base analog fluorodeoxyuridine, which may act through a different biochemical mechanism from FU but also suppresses cell division (13), inhibits the elongation of the roots from irradiated seeds only slightly.

When $5 \mathrm{~mm}$ sections are taken from the corn roots starting $3 \mathrm{~mm}$ from the tip to include the elongation zone (5), the limited growth of these sections is not inhibited by FU or MH (Table 1). Similarly, MH and FU do not affect the elongation of a $10 \mathrm{~mm}$ segment of the root including the tip. Omission of the potassium phosphate or pyridoxal did not alter the effect of $\mathrm{MH}$ and $\mathrm{FU}$ or the amount of growth. Since all the nutrients required for the culture of roots were not added (25), these excised root tips probably have little mitotic activity in their apical meristem, and elongation probably does not depend on continued cell division. Regardless of whether there is any cell division or not the roots grow by cell enlargement and since growth is not inhibited neither is cell enlargement.

Taken together these results suggest that MH inhibits corn root elongation by suppressing cell division; thus it is possible that the long delay in inhibition is due to continued cell enlargement until the supply of small, potentially expandable cells is exhausted. The question of whether or not MH inhibits cell expansion is important because cell enlargement requires the normal 

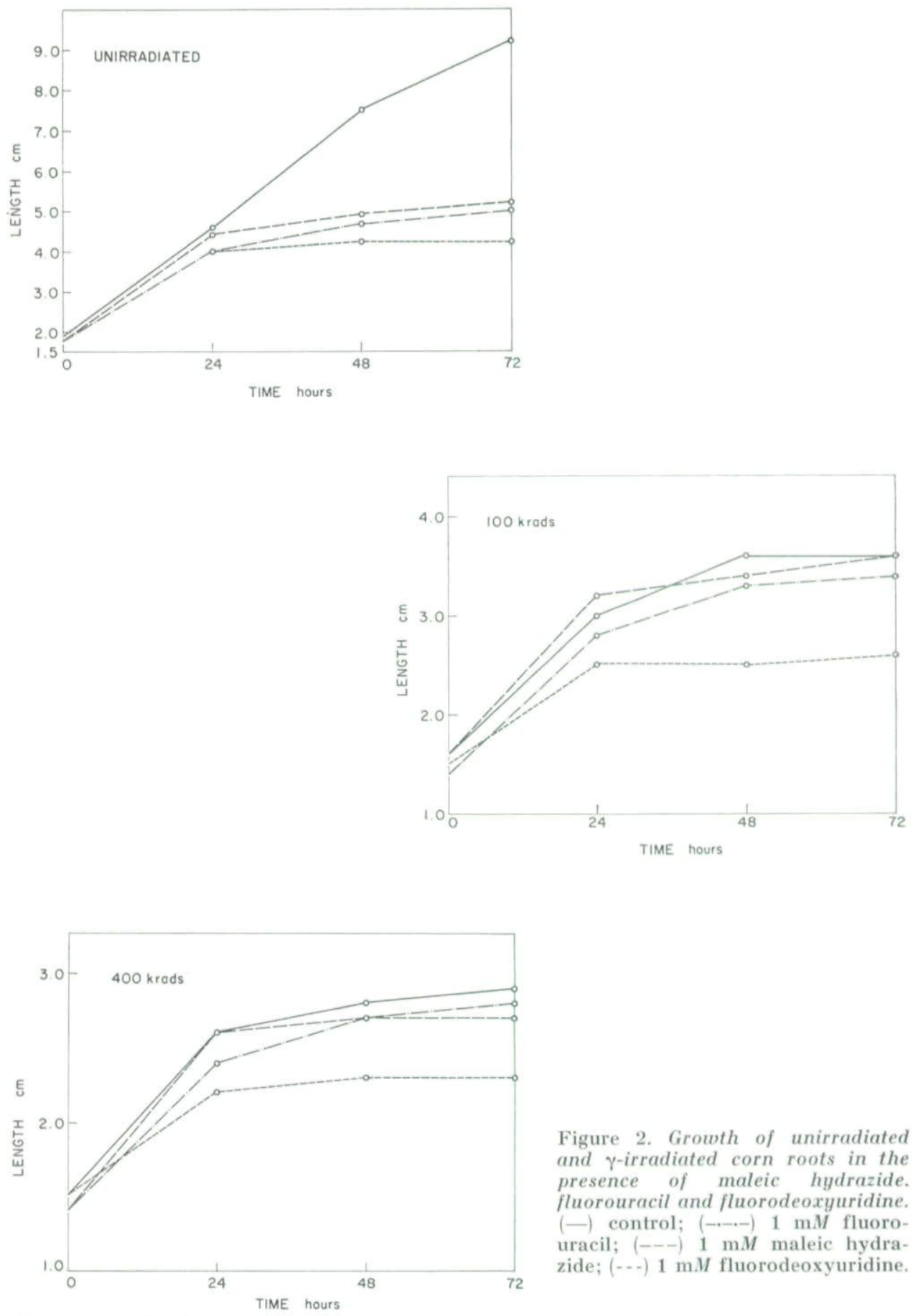

Figure 2. Growth of unirradiated and $\gamma$-irradiated corn roots in the presence of maleic hydrazide. fluorouracil and fluorodeoxyuridine. (-) control; (-,--) $1 \mathrm{mM}$ fluorouracil; (---) $1 \mathrm{mM}$ maleic hydrazide; (..) $1 \mathrm{mM}$ fluorodeoxyuridine.

Physiol. Plant., 22, 1969 
Table 1. Failure of maleic hydrazide and fluorouracil to inhibit the growth of sections from corn seedling roots. - The treatment solutions contained $2 \%$ sucrose, $5 \mathrm{mM} \mathrm{KH}_{2} \mathrm{PO}_{4}$ (pH 5.5) and $0.1 \mathrm{~m} M$ pyridoxal. Average initial root length $2.2 \mathrm{~cm}$.

\begin{tabular}{|c|c|c|c|}
\hline \multirow{2}{*}{ Type of section } & \multicolumn{2}{|c|}{ Treatment } & \multirow{2}{*}{$\begin{array}{c}\text { Increase in } \\
\text { fresh weight } \\
\text { in } 24 \text { hours } \\
0 \%\end{array}$} \\
\hline & $1 \mathrm{~m} M \mathrm{FU}$ & $1 \mathrm{~m} M \mathrm{MH}$ & \\
\hline
\end{tabular}

$5 \mathrm{~mm}$ starting $\ldots \ldots \ldots \ldots \ldots \ldots \ldots \ldots \ldots$

$3 \mathrm{~mm}$ from the tip $\ldots \ldots \ldots \ldots \ldots \ldots \ldots$

$\begin{array}{lll}- & - & 35 \\ - & 0.1 & 32 \\ \overline{-} & 1.0 & 38 \\ 1.0 & 5.0 & 35 \\ - & - & 39 \\ \overline{1.0} & \overline{1.0} & 83 \\ 1.0 & \overline{1.0} & 80 \\ & & 90\end{array}$

functioning of a considerable portion of the cell's metabolic machinery, ATP production, protein synthesis, etc. (see 2, 22) and thus a lack of inhibition would indicate some degree of specificity. For this reason the question was explored further using auxin-controlled cell expansion in several tissues including corn coleoptile sections.

MH $(1 \mathrm{mM})$ also failed to inhibit IAA-induced cell enlargement in corn coleoptile sections and artichoke tuber disks (Table 2). Even $5 \mathrm{mM}$ MH only slightly inhibits IAA-induced growth in the coleoptile sections, but it does inhibit IAA-induced growth in artichoke tuber disks. Since the MH at $1 \mathrm{~m} M$ is present in an eighteen fold excess compared to the IAA on a molar basis, it is unlikely that $\mathrm{MH}$ is a very effective antiauxin. In contrast to the other tissues tested here, cell enlargement promoted by IAA in tobacco pith explants is very sensitive to $\mathrm{MH}$ being inhibited by concentrations as low as $10^{-5} M$ (Table 2). Perhaps pith tissues are unusually sensitive to MH; long ago

Table 2. Effect of maleic hydrazide on IAA-induced growth.

\begin{tabular}{|c|c|c|c|c|c|c|c|}
\hline \multicolumn{2}{|c|}{ Treatment } & \multicolumn{6}{|c|}{ Increase in fresh weight, $\%$} \\
\hline \multirow{2}{*}{$\begin{array}{c}\text { IAA } \\
10 \mathrm{mg} / 1\end{array}$} & \multirow{2}{*}{$\begin{array}{l}\mathrm{MH} \\
\mathrm{m} M\end{array}$} & \multirow{2}{*}{$\begin{array}{c}\text { Subapical } \\
\text { corn } \\
\text { coleoptile } \\
\text { sections } \\
\text { in } 20 \mathrm{~h}\end{array}$} & \multicolumn{4}{|c|}{ Aged artichoke tuber disks } & \multirow{2}{*}{$\begin{array}{c}\text { Tobacco } \\
\text { pith } \\
\text { explants } \\
\text { in } 12 \text { days }\end{array}$} \\
\hline & & & in $12 \mathrm{~h}$ & in $24 \mathrm{~h}$ & in $48 \mathrm{~h}$ & in $72 \mathrm{~h}$ & \\
\hline - & - & 30 & 5 & 6 & 8 & 7 & 29 \\
\hline - & 0.1 & 30 & - & - & - & - & - \\
\hline - & 1 & 24 & - & - & - & - & 27 \\
\hline - & 5 & 22 & - & - & - & - & - \\
\hline+ & - & 54 & 6 & 19 & 43 & 53 & 191 \\
\hline+ & 0.01 & - & - & - & - & - & 175 \\
\hline+ & 0.1 & 54 & - & - & - & - & 140 \\
\hline+ & 0.5 & - & 6 & 16 & 48 & 59 & - \\
\hline+ & 1 & 51 & 6 & 15 & 40 & 50 & 35 \\
\hline \multirow[t]{2}{*}{+} & 5 & 46 & 6 & 12 & 17 & 19 & \\
\hline & & & & & & Phys & 'lant., 22, 1 \\
\hline
\end{tabular}


Table 3. Effect of short exposures to maleic hydrazide on elongation of corn seedling roots (cumulative increase in root length, cm). Average initial root length $2.3 \mathrm{~cm}$.

\begin{tabular}{|c|c|c|c|c|c|c|c|}
\hline \multirow{2}{*}{$\begin{array}{l}\text { Time after start } \\
\text { hours }\end{array}$} & \multicolumn{7}{|c|}{$\begin{array}{l}\text { Incubation in } 1 \mathrm{~m} M \text { MH before transfer to } \mathrm{H}_{2} \mathrm{O} \\
\text { hours }\end{array}$} \\
\hline & 0 & $1 / 2$ & 1 & 4 & 12 & 24 & 72 \\
\hline $24 \ldots \ldots \ldots \ldots \ldots$ & 4.1 & 3.4 & 3.1 & 2.9 & 2.6 & 2.8 & 2.5 \\
\hline $48 \ldots \ldots \ldots \ldots \ldots$ & 7.6 & 5.5 & 5.1 & 4.0 & 3.7 & 3.7 & 3.3 \\
\hline $72 \ldots \ldots \ldots \ldots \ldots$ & 8.4 & 6.3 & 5.7 & 4.2 & 3.9 & 3.9 & 3.5 \\
\hline
\end{tabular}

Greulach and Haesloop (9) observed that MH tended to inhibit cell enlargement in the center of tomato stems to a greater extent; thus cell enlargement in some tissues can be inhibited by MH. Other investigators have also observed that $\mathrm{MH}$ may inhibit auxin-induced growth or not depending on the tissue and the conditions of application $(1,6,7,8,9,10,11,15,26,28,31)$. Usually MH does not inhibit cell enlargement, but sometimes it can, particularly at high concentrations.

In order to determine the length of the exposure to MH required to produce maximum inhibition and to determine if recovery occurs after short exposures to $\mathrm{MH}$, corn roots were treated with $1 \mathrm{~m} M \mathrm{MH}$ for varying lengths of time and then transferred to water (Table 3). As little as 12 hours of treatment produced maximal inhibition; however, a four-hour treatment had almost as much effect. Although no tendency to recover was observed here, it has been reported for lower concentrations of $\mathrm{MH}$ in other roots (18).

Another approach which has been widely used to study the action of MH is the use of various compounds to counteract the inhibitory effect of MH. A variety of compounds including uracil (11), $\mathrm{CoCl}_{2}$, cysteine (26), cystamine (20), pyruvate, pyridoxal (27), guanosine and thymine (14) have been shown to ameliorate the effects of $\mathrm{MH}$ on other systems. Most of these compounds were tested in concentrations equal to or greater than those used in the original investigations, but none is able to prevent the inhibitory action of MH on corn roots (Table 4). In addition to those shown in Table 4, a variety of other compounds such as thymidine, uridine, orotate, adenosine and thiamine were tested, but they too were unable to prevent the effect of $\mathrm{MH}$. Most of these were also tested on pea seedling roots with essentially the same results, namely no preventative effect. Some, especially pyridoxal, markedly promoted root elongation in the absence of $\mathrm{MH}$. Under some circumstances such as with adenosine (Table 4 ), this could be mistaken for a true "reversal" of the inhibitor. For gibberellin $(\mathbf{1 0}, 11)$, auxin $(1,19)$, kinetin (19) and several pyrimidines including uracil $(13,16,23)$, tests on other plant tissues have already failed to produce any substantial reduction of the inhibition due to MH. So far, the data on corn roots do not support and, within the limitations imposed by the small number of molecules tested, even argue against the theory that MH inhibits the synthesis of or competes with any simple metabolite or hormone.

These and earlier studies (see for example 8, 9, 10) support the idea that MH influences plant development mainly through its effect on cell division. Although lower concentrations of MH suffice to cause chromosome breakage Physiol. Plant., 22, 1969 
Table 4. Effect of reputed antagonists of maleic hydrazide on its inhibition of corn seedling root growth. - Average initial root length $2.2-2.7 \mathrm{~cm}$ depending on the experiment.

\begin{tabular}{|c|c|c|}
\hline Treatment & $\begin{array}{l}\text { Incubation } \\
\text { hours }\end{array}$ & $\begin{array}{c}\text { Change } \\
\text { in root length } \\
\mathrm{cm}\end{array}$ \\
\hline 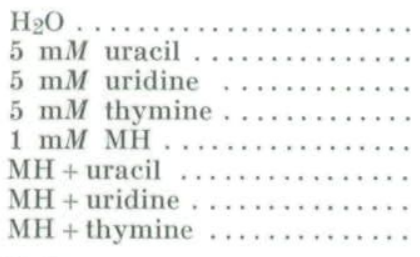 & $\begin{array}{l}- \\
- \\
- \\
- \\
-\end{array}$ & $\begin{array}{l}7.1 \\
7.8 \\
7.4 \\
9.7 \\
9.7 \\
3.9 \\
3.5 \\
4.1 \\
4.4\end{array}$ \\
\hline $\begin{array}{l}\mathrm{H}_{2} \mathrm{O} \\
1 \mathrm{~m} M \text { thymidine } \ldots \ldots \ldots \cdots \\
1 \mathrm{~m} M \text { MH } \ldots \cdots \cdots \\
\mathrm{MH}+\text { thymidine } \ldots \ldots \ldots \ldots\end{array}$ & $\begin{array}{l}48 \\
- \\
-\end{array}$ & $\begin{array}{l}5.3 \\
6.6 \\
3.0 \\
3.1\end{array}$ \\
\hline $\begin{array}{l}\mathrm{H}_{2} \mathrm{O} \ldots \ldots \ldots \ldots \\
1 \mathrm{~m} M \text { adenosine } \ldots \ldots \ldots \ldots \\
1 \mathrm{~m} M \text { MH } \ldots \ldots \ldots \ldots \\
\mathrm{MH}+\text { adenosine } \ldots \ldots \ldots \ldots\end{array}$ & $\begin{array}{l}48 \\
- \\
-\end{array}$ & $\begin{array}{l}6.1 \\
7.4 \\
3.7 \\
4.4\end{array}$ \\
\hline $\begin{array}{l}\mathrm{H}_{2} \mathrm{O} \\
5 \mathrm{~m} M \\
1 \mathrm{~m} \text { pyridoxal } \\
1 \mathrm{~m} M \\
\mathrm{MH}+\ldots \ldots \ldots\end{array}$ & $\begin{array}{l}48 \\
- \\
-\end{array}$ & $\begin{array}{l}6.1 \\
8.3 \\
3.7 \\
3.6\end{array}$ \\
\hline 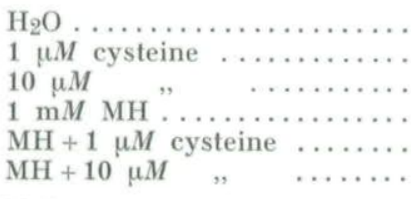 & $\begin{array}{l}48 \\
- \\
- \\
-\end{array}$ & $\begin{array}{l}6.1 \\
4.2 \\
4.6 \\
3.2 \\
2.4 \\
2.9\end{array}$ \\
\hline $\begin{array}{l}\mathrm{H}_{2} \mathrm{O} \\
1 \mu M \\
1 \\
1 \mathrm{~m} M \mathrm{CoCl}_{2}^{\mathrm{MH}} \ldots \ldots \ldots \ldots \ldots \ldots \ldots\end{array}$ & $\begin{array}{l}24 \\
\text { - } \\
-\end{array}$ & $\begin{array}{l}4.7 \\
5.0 \\
3.3 \\
3.3\end{array}$ \\
\hline 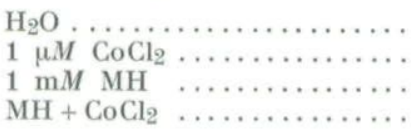 & $\frac{48}{-}$ & $\begin{array}{l}9.3 \\
7.6 \\
4.1 \\
4.1\end{array}$ \\
\hline
\end{tabular}

than for inhibition of cell division (18), both could be produced by the same mechanism, a higher level of damage being required to suppress cell division. It may be very significant that heterochromatic regions of chromosomes are affected preferentially $(13,18)$ and species with more heterochromatin do seem to be more sensitive $(13,18)$. Thus the primary effect of $\mathrm{MH}$ may be on the metabolism of the proteins or nucleic acids of chromatin. Although the action of $\mathrm{MH}$ on root growth resembles that of $\mathrm{FU}$, the similarity may end with their ability to suppress cell division without inhibiting cell expansion. This notion is supported by the observation that the inhibitory effect of FU may be prevented at least partially by simultaneous application of thymidine but not thymine or uridine (Table 5) whereas the MH effect is not (Table 4). 
Table 5. Effect of antagonists of fluorouracil on its inhibition of pea seedling root grouth. - Average initial root length $2.5 \mathrm{~cm}$.

\begin{tabular}{|c|c|c|c|}
\hline \multirow{2}{*}{ Treatment } & \multicolumn{3}{|c|}{ Change in root length, $\mathrm{cm}$} \\
\hline & after $24 \mathrm{~h}$ & after $48 \mathrm{~h}$ & after $72 \mathrm{~h}$ \\
\hline $\mathrm{H}_{2} \mathrm{O}$ & 1.8 & 2.9 & 3.5 \\
\hline $1 \mathrm{~m} M$ thymine $\ldots \ldots \ldots \ldots \ldots \ldots \ldots$ & 1.7 & 3.1 & 3.9 \\
\hline $1 \mathrm{~m} M$ thymidine $\ldots \ldots \ldots \ldots \ldots \ldots$ & 1.7 & 2.9 & 3.5 \\
\hline $1 \mathrm{~m} M$ uridine $\ldots \ldots \ldots \ldots \ldots \ldots \ldots$ & 1.6 & 2.5 & 3.0 \\
\hline $1 \mathrm{~m} M$ fluorouracil $\ldots \ldots \ldots \ldots \ldots \ldots \ldots$ & 1.1 & 1.3 & 1.3 \\
\hline $\mathrm{FU}+$ thymine $\ldots \ldots \ldots \ldots \ldots \ldots \ldots \ldots \ldots$ & 1.3 & 1.5 & 1.5 \\
\hline $\mathrm{FU}+$ thymidine $\ldots \ldots \ldots \ldots \ldots \ldots \ldots$ & 1.5 & 2.2 & 2.4 \\
\hline $\mathrm{FU}+$ uridine $\ldots \ldots \ldots \ldots \ldots \ldots \ldots \ldots$ & 1.1 & 1.2 & 1.2 \\
\hline
\end{tabular}

The same results were obtained with corn roots and FU. In contrast to FU the inhibitory effect of $1 \mathrm{~m} M$ FUdR on corn root growth is almost completely prevented by $1 \mathrm{~m} M$ thymidine.

While the inhibition of cell division is certainly very important, it may not account for all the developmental aberrations such as inhibition of cell enlargement and the effects on phloem which have been observed to result from treatment with MH $(3,8,11,29,30,31)$. MH has been shown to cause defects in the phloem after exposures which are very long compared to those used here, but this is probably not the primary mean by which MH affects plant development. Certainly, the inhibition of cell division is not mediated through an effect on the phloem because it suppresses cell division in tissue cultures where a dependence on phloem transport is eliminated (23). Moreover, the failure of MH to inhibit the elongation of roots from $\gamma$-irradiated seeds as it does unirradiated roots argues against the possibility that $\mathrm{MH}$ inhibits root elongation through an effect on phloem function. The drastic reduction in the amount of elongation in $1 \mathrm{~cm}$ root tips when they are excised (Table 1) indicates that the normal phloem function is still needed to supply nutrients from the seed. Since the same is true for roots from irradiated seeds, it follows then that $\mathrm{MH}$ does not interfere with phloem function during the growth of the roots in the $\gamma$-irradiated seeds.

Although $\mathrm{MH}$ has long been suspected to inhibit plant growth mainly through an effect on cell division rather than cell enlargement, the evidence generally has not been clear cut. At least in the case of corn roots, $\mathrm{MH}$ inhibits cell division but not enlargement. Similarly IAA-induced growth in corn coleoptiles is not inhibited by MH. Since cell enlargement is known to require active metabolism including ATP and protein synthesis (see 2, 22), it follows that MH does not significantly interfere with these. Thus, MH appears to be relatively selective in its action.

Studies on the metabolism of MH and its effects on nucleic acid synthesis will be presented in other papers.

This work was supported in part by Institutional Research Grant No. IN-40 G to the University of Michigan from the American Cancer Society and in part by a grant from the National Science Foundation (GB-5502). 
The author is also greatly indebted to Richard M. Tetley for his help with the experiments with tobacco pith and to Janet L. Ristow for her skillful technical assistance.

\section{References}

1. Åberg, B.: On the interaction of 2,3,5-triiodobenzoic acid and maleic hydrazide with auxins. - Physiol. Plant. 6: 277-291. 1953.

2. Cleland, R.: The relation between auxin and metabolism. - Encyclopedia of Plant Physiol. 14: 755-783. 1961.

3. Crafts, A. S.: The Chemistry and Mode of Action of Herbicides. - Interscience Publishers. New York. 1964.

4. Deysson, G. \& Truhaut, R.: Antimitotic properties of antagonists of natural pyrimidine bases. I. 5-Fluorouracil and related compounds. - Bull. Soc. Chim. Biol. 44:513524. 1962.

5. Erickson, R. O. \& Goddard, D. R.: Analysis of root growth in cellular and biochemical terms. - Growth. Symposium on Development and Growth 15 (suppl.) : 88-116. 1951.

6. Foster, R. J., McRae, D. H. \& Bonner, J.: Auxin-antiauxin interaction at high auxin concentrations. - Plant Physiol. 30: 323-327. 1955.

7. Gautheret, R. J.: Recherches sur l'action combinée de l'hydrazide maléique et de l'acide indoleacétique sur les cultures de tissues de Topinambour. - C. R. Acad. Sei. Paris 234: 2218-2221. 1952.

8. Gifford, E. M.: Some anatomical and cytological responses of barley to maleic hydrazide. - Amer. Jour. Bot. 43: 72-80. 1956.

9. Greulach, V. A. \& Haesloop, J. G.: Some effects of maleic hydrazide on internode elongation, cell enlargement, and stem anatomy. - Ibid. 41:44-50. 1954.

10. Haber, A. H. \& White, J. D.: Action of maleic hydrazide on dormancy, cell division, and cell expansion. - Plant Physiol. 35: 495-499. 1960.

11. Hoffman, I. \& Parups, E. V.: Mode of action of maleic hydrazide in relation to residues in crops and soils. - Residue Reviews 7:96-113. 1964.

12. Jojima, T. \& Tamura, S.: Herbicidal activity of some pyridazine derivatives. Part II. 3-halo- and 3-anilo-6-phenoxypyridazines and related compounds. - Agricult. Biol. Chem. 29: 157-161. 1965.

13. Kihlman, B. A.: Actions of Chemicals on Dividing Cells. - Prentice-Hall, Inc., New Jersey, 1966.

14. Kim, W. K. \& Greulach, V. A.: A comparative study of some influences of maleic hydrazide and 5-fluorouracil on the metabolism of Chlorella pyrenoidosa. - Phyton 20: 127-136. 1963.

15. Leopold, A. C. \& Klein, W. H.: Maleic hydrazide as an antiauxin. - Physiol. Plant. 5: 91-99. 1952.

16. Loveless, A.: Chemical and biochemical problems arising from the study of chromosome breakage by alkylating agents and heterocyclic compounds. - Heredity 6 (suppl.) : 293-298. 1952.

17. Maravolo, N. C. \& Voth, P. D.: Morphogenic effects of three growth substances in Marchantia gemmalings. - Bot. Gaz. 127: 79-86, 1966.

18. McLeish, J.: The action of maleic hydrazide in Vicia. - Heredity 6 (suppl.) : 125-147. 1952.

19. McManus, M. A.: Certain mitotic effects of kinetin, gibberellic acid, indoleacetic acid, and maleic hydrazide on the root of Allium cepa. - Nature 185:44-45. 1960.

20. Moutschen, J.: Modifications with cystamine of chromosome damage caused by maleic hydrazide in broad bean. - Radiobiol. latina 3:271-277. 1960.

21. Murashige, T. \& Skoog, F.: A revised medium for rapid growth and bioassays with tobacco tissue cultures. - Physiol. Plant. 15: 473-497. 1962.

22. Noodén, L. D.: Studies on the role of RNA synthesis in auxin induction of cell enlargement. - Plant Physiol. 43: 140-150. 1968.

23. Schaeffer, G. W. \& Sorokin, T.: Growth inhibition of tobacco tissue cultures with 6-azauracil, 6-azauridine and maleic hydrazide. - Ibid. 41:971-975. 1966.

24. Schwartz, D. \& Bay, C. E.: Further studies on the reversal in the seedling height dose curve at very high levels of ionizing radiations. - Amer. Naturalist 90: 323-327. 1956. 
25. Street, H. E.: Excised root culture. - Biol. Rev. 32: 117-155. 1957.

26. Suda, S.: Mode of action of maleic hydrazide on the growth of Escherichia coli and Avena coleoptile sections. - Plant and Cell Physiol. 1:247-253. 1960.

27. Suzuki, Y.: Maleic hydrazide and isonicotinyl hydrazide as carbonyl reagents. - Physiol. Plant. 19: 257-263. 1966 .

28. Taylorson, R. \& Holm, L. G.: Maleic hydrazide-auxin interactions in water uptake of potato disks. - Plant Physiol. 36: 465-471. 1961.

29. Thompson, P. A.: Reversal of photoperiodic induction of strawberries with maleic hydrazide. - Nature 200: 146-148. 1963.

30. Wardlaw, C. W.: Experimental and analytical studies of pteridophytes. XXXV. The effects of direct applications of various substances to the shoot apex of Dryopteris austriaca (D. aristata). - Ann. Bot. N.S. 21: 85-120. 1957.

31. Zukel, J. W. (compiler): A Literature Summary on Maleic Hydrazide. 1957-1963. Naugatuck Chemical Division, U.S. Rubber Co. 1963. 
This document is a scanned copy of a printed document. No warranty is given about the accuracy of the copy. Users should refer to the original published version of the material. 